\title{
Endoscopic appearance of esophageal xanthoma
}

\section{(ㄷ)(이우}

\author{
Authors \\ Kenta Hamada1,2, Noriya Uedo ${ }^{1}$, Chiaki Kubo ${ }^{3}$, Yasuhiko Tomita ${ }^{3}$, Ryu Ishihara ${ }^{1}$, Yasushi Yamasaki ${ }^{1,2}$, Masayasu

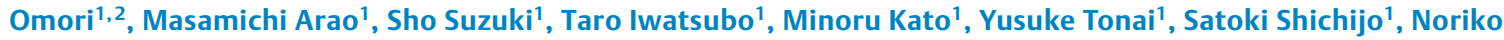 \\ Matsuura ${ }^{1}$, Hiroko Nakahira ${ }^{1}$, Takashi Kanesaka ${ }^{1}$, Sachiko Yamamoto ${ }^{1}$, Tomofumi Akasaka ${ }^{1}$, Noboru Hanaoka ${ }^{1}$, Yoji \\ Takeuchi $^{1}$, Koji Higashino ${ }^{1}$, Hiroyuki Okada ${ }^{2}$, Hiroyasu lishi ${ }^{1}$
}

Institutions

1 Department of Gastrointestinal Oncology, Osaka International Cancer Institute, 3-1-69 Otemae, Chuo-ku, Osaka 541-8567, Japan

2 Department of Gastroenterology and Hepatology, Okayama University Graduate School of Medicine, Dentistry and Pharmaceutical Sciences, 2-5-1 Shikatacho, Kita-ku, Okayama 700-8558, Japan

3 Department of Pathology, Osaka International Cancer Institute, 3-1-69 Otemae, Chuo-ku, Osaka 541-8567, Japan

submitted 2.4.2019

accepted after revision 22.5.2019

\author{
Bibliography \\ DOI https://doi.org/10.1055/a-0966-8544 | \\ Endoscopy International Open 2019; 07: E1214-E1220 \\ (c) Georg Thieme Verlag KG Stuttgart · New York \\ eISSN 2196-9736
}

Corresponding author

Noriya Uedo, MD, Department of Gastrointestinal

Oncology, Osaka International Cancer Institute, 3-1-69,

Otemae, Chuo-ku, Osaka 541-8567, Japan

Fax: +81-66-9451902

uedou-no@mc.pref.osaka.jp

\section{ABSTRACT}

Background and study aims Esophageal xanthomas are considered to be rare, and their endoscopic diagnosis has not been fully elucidated. The aim of the present study was to determine the characteristics of the endoscopic appearance of esophageal xanthomas.

Patients and methods This was a retrospective study of consecutive patients with histologically diagnosed esophageal xanthomas at a referral cancer center in Japan. The endoscopic appearance, by magnifying or image-enhanced endoscopy, and histological findings of esophageal xanthomas were investigated.

Results Seven patients (six men and one woman) were enrolled. All of the patients had a solitary lesion, and the median size was $2 \mathrm{~mm}$ (range, $1-5 \mathrm{~mm}$ ). Conventional whitelight endoscopy showed the lesions as flat areas with yellowish spots in four cases and slightly elevated yellowish lesions in three cases. Magnifying endoscopy, performed in six patients, revealed the lesions as areas with aggregated minute yellowish spots with tortuous microvessels inside. Magnifying narrow-band imaging contrasted the yellowish spots and microvessels better than white-light endoscopy. In all lesions, histological examination showed that the yellowish spots corresponded to papillae filled with foam cells. The foam cells were strongly immunopositive for CD68, and in all lesions, CD34-positive intrapapillary capillaries surrounded the aggregated foam cells. The different morphologies of the flat and slightly elevated lesions corresponded to different densities of papillae filled with foam cells.

Conclusions Magnifying endoscopy revealed minute yellowish spots with tortuous microvessels inside. These correspond well with histological findings and so may be useful in the diagnosis of esophageal xanthomas.

\section{Introduction}

Xanthomas are non-neoplastic lesions resulting from the accumulation of foamy histiocytes, which are characteristically found in the oral cavity and genital skin [1]. Xanthomas in the gastrointestinal tract are asymptomatic and can be discovered incidentally during gastrointestinal endoscopy for other condi- tions [2]. The majority of gastrointestinal xanthomas are found in the stomach. In Japan, gastric xanthomas are especially common [3] because of the high prevalence of Helicobacter pylori infection and chronic atrophic gastritis in this population. As such, endoscopic characteristics have been established within the Japanese population and the lesion is usually only diagnosed by endoscopic findings and without the use of biopsies. 
- Table 1 Patient and endoscope characteristics.

\begin{tabular}{|c|c|c|c|c|c|c|c|c|}
\hline $\begin{array}{l}\text { Patient } \\
\text { no. }\end{array}$ & Sex & $\begin{array}{l}\text { Age, } \\
\text { years }\end{array}$ & Comorbidities & Past histories & $\begin{array}{l}\text { Drink- } \\
\text { ing }\end{array}$ & $\begin{array}{l}\text { Smok- } \\
\text { ing }\end{array}$ & $\begin{array}{l}\text { Purpose of } \\
\text { endoscopy }\end{array}$ & $\begin{array}{l}\text { Type of } \\
\text { endoscope }\end{array}$ \\
\hline 1 & Male & 68 & $\begin{array}{l}\text { DM, reflux esophagitis, } \\
\text { HT, gastric SMT }\end{array}$ & None & Current & Current & $\begin{array}{l}\text { SMT surveil- } \\
\text { lance }\end{array}$ & GIF-H260Z \\
\hline 2 & Male & 71 & Atrophic gastritis, HT & $\begin{array}{l}\text { Laryngeal cancer, } \\
\text { gastric cancer }\end{array}$ & Current & Former & $\begin{array}{l}\text { Cancer sur- } \\
\text { veillance }\end{array}$ & GIF-RQ260Z \\
\hline 3 & Male & 67 & None & $\begin{array}{l}\text { Esophageal cancer, } \\
\text { gastric cancer }\end{array}$ & Former & Former & $\begin{array}{l}\text { Cancer sur- } \\
\text { veillance }\end{array}$ & GIF-RQ260Z \\
\hline 4 & Male & 67 & $\begin{array}{l}\mathrm{HL}, \mathrm{HT} \text {, benign prostatic } \\
\text { hyperplasia }\end{array}$ & $\begin{array}{l}\text { Esophageal cancer, } \\
\text { laryngeal cancer }\end{array}$ & Current & Former & $\begin{array}{l}\text { Cancer sur- } \\
\text { veillance }\end{array}$ & GIF-H260Z \\
\hline 5 & Male & 59 & $\begin{array}{l}\text { HL, old myocardial } \\
\text { infarction }\end{array}$ & Esophageal cancer & Current & Former & $\begin{array}{l}\text { Cancer sur- } \\
\text { veillance }\end{array}$ & GIF-Q240Z \\
\hline 6 & Female & 71 & $\begin{array}{l}\text { Esophageal cancer, } \\
\text { atrophic gastritis, HT, PAF }\end{array}$ & $\begin{array}{l}\text { Esophageal cancer, } \\
\text { IPMN }\end{array}$ & Current & Former & $\begin{array}{l}\text { Cancer sur- } \\
\text { veillance }\end{array}$ & GIF-HQ290 \\
\hline 7 & Male & 78 & Chronic hepatitis C & $\begin{array}{l}\text { Esophageal cancer, } \\
\text { renal cancer } \\
\text { DU, cholecystolithia- } \\
\text { sis, alcoholism }\end{array}$ & Former & Former & $\begin{array}{l}\text { Cancer sur- } \\
\text { veillance }\end{array}$ & GIF-Q240Z \\
\hline
\end{tabular}

DM: diabetes mellitus, HT: hypertension, SMT: submucosal tumor, HL: hyperlipidemia, PAF: paroxysmal atrial fibrillation, IPMN: intraductal papillary mucinous neoplasm, DU: duodenal ulcer.

However, since esophageal xanthomas are rare, and only 17 cases have been described in the English literature before the present study [4-17], endoscopic diagnosis of esophageal xanthomas have not been thoroughly investigated. In this study, therefore, using magnifying or image-enhanced endoscopy, we examined the endoscopic appearance of esophageal xanthomas which were diagnosed histologically in our hospital.

\section{Patients and methods}

This was a retrospective observational study performed at a referral cancer center in Japan. Consecutive patients who were histologically diagnosed as having esophageal xanthoma at the Osaka International Cancer Institute between 1 July 2016 and 28 February 2017 were abstracted from our database of pathology. Written informed consent for study participation was waived as only anonymous retrospective data were used in this study. The study protocol was approved by the institutional review board of Osaka International Cancer Institute.

\section{Endoscopy}

Four types of upper gastrointestinal endoscope (GIF-Q240Z, GIF-H260Z, GIF-RQ260Z, and GIF-HQ290; Olympus Optical Co., Tokyo, Japan) were used in this study. Magnifying endoscopy with narrow-band imaging (NBI) was performed in all cases apart from one patient who underwent endoscopic examination with GIF-HQ290. Biopsies were performed in all cases.

\section{Histological examination}

The biopsy specimens were routinely fixed in $10 \%$ formalin, processed, and stained with hematoxylin and eosin. In all cases, immunohistochemical staining was performed with antibodies for CD68 and CD34.

\section{Measured outcomes}

The endoscopic appearance, by magnifying or image-enhanced endoscopy, and histological findings of esophageal xanthomas were investigated in order to elucidate the characteristics of esophageal xanthomas. Age, sex, comorbidities, medical history, drinking history, and smoking history were investigated to assess the etiology and significance of esophageal xanthomas.

\section{Results}

Among the 685 patients from whom biopsy samples were collected from the esophagus during the study period, 7 had an esophageal xanthoma. The patient and lesion characteristics of these 7 patients are shown in $>$ Table 1 and $>$ Table 2 . The patients were six men and one woman with median age of 68 years (range, 59-78 years). Noticeable $(n \geq 2)$ comorbidities and past histories were as follows: esophageal squamous cell carcinoma $(n=5)$, radiation therapy of the lesion area $(n=4)$, head and neck cancer $(n=2)$, hyperlipidemia $(n=2)$, gastric cancer $(n=2)$, atrophic gastritis $(n=2)$. All patients had both drinking and smoking habits.

All of the patients had a solitary lesion with a median size of $2 \mathrm{~mm}$ (range, $1-5 \mathrm{~mm}$ ). Although the lesions were found throughout the esophagus, they were most likely to be found 
- Table 2 Lesion characteristics.

\begin{tabular}{|c|c|c|c|c|c|c|c|c|}
\hline $\begin{array}{l}\text { Pa- } \\
\text { tient } \\
\text { no. }\end{array}$ & $\begin{array}{l}\text { No. of } \\
\text { lesions }\end{array}$ & $\begin{array}{l}\text { Loca- } \\
\text { tion }\end{array}$ & $\begin{array}{l}\text { Size, } \\
\mathrm{mm}\end{array}$ & $\begin{array}{l}\text { White light } \\
\text { endoscopic } \\
\text { finding }\end{array}$ & $\begin{array}{l}\text { Magnifying endoscopic } \\
\text { appearance }\end{array}$ & $\begin{array}{l}\text { Histological } \\
\text { findings }\end{array}$ & CD68 & $\begin{array}{l}\text { CD34 (intrapa- } \\
\text { pillary capillar- } \\
\text { ies around the } \\
\text { foam cells) }\end{array}$ \\
\hline 1 & Solitary & Ut & 2 & $\begin{array}{l}\text { Slightly elevated } \\
\text { yellowish lesion }\end{array}$ & $\begin{array}{l}\text { Aggregation of minute } \\
\text { yellowish spots with tortu- } \\
\text { ous microvessels inside }\end{array}$ & $\begin{array}{l}\text { Foam cells in the } \\
\text { papillae and LPM }\end{array}$ & $\begin{array}{l}\text { Posi- } \\
\text { tive }\end{array}$ & Positive \\
\hline 2 & Solitary & Mt & 1 & $\begin{array}{l}\text { Flat area with } \\
\text { yellowish granu- } \\
\text { lar spots }\end{array}$ & $\begin{array}{l}\text { Aggregation of minute } \\
\text { yellowish spots with tortu- } \\
\text { ous microvessels inside }\end{array}$ & $\begin{array}{l}\text { Foam cells in the } \\
\text { papillae }\end{array}$ & $\begin{array}{l}\text { Posi- } \\
\text { tive }\end{array}$ & Positive \\
\hline 3 & Solitary & $\mathrm{Ce}$ & 3 & $\begin{array}{l}\text { Flat area with } \\
\text { yellowish granu- } \\
\text { lar spots }\end{array}$ & $\begin{array}{l}\text { Aggregation of minute } \\
\text { yellowish spots with tortu- } \\
\text { ous microvessels inside }\end{array}$ & $\begin{array}{l}\text { Foam cells in the } \\
\text { papillae }\end{array}$ & $\begin{array}{l}\text { Posi- } \\
\text { tive }\end{array}$ & Positive \\
\hline 4 & Solitary & Ut & 2 & $\begin{array}{l}\text { Flat area with } \\
\text { yellowish granu- } \\
\text { lar spots }\end{array}$ & $\begin{array}{l}\text { Aggregation of minute } \\
\text { yellowish spots with tortu- } \\
\text { ous microvessels inside }\end{array}$ & $\begin{array}{l}\text { Foam cells in the } \\
\text { papillae and LPM }\end{array}$ & $\begin{array}{l}\text { Posi- } \\
\text { tive }\end{array}$ & Positive \\
\hline 5 & Solitary & $\mathrm{Lt}$ & 1 & $\begin{array}{l}\text { Slightly elevated } \\
\text { yellowish lesion }\end{array}$ & $\begin{array}{l}\text { Aggregation of minute } \\
\text { yellowish spots with tortu- } \\
\text { ous microvessels inside }\end{array}$ & $\begin{array}{l}\text { Foam cells in the } \\
\text { papillae }\end{array}$ & 1 & Positive \\
\hline 6 & Solitary & $\mathrm{Ce}$ & 5 & $\begin{array}{l}\text { Flat area with } \\
\text { yellowish granu- } \\
\text { lar spots }\end{array}$ & Not performed & $\begin{array}{l}\text { Foam cells in the } \\
\text { papillae }\end{array}$ & $\begin{array}{l}\text { Posi- } \\
\text { tive }\end{array}$ & Positive \\
\hline 7 & Solitary & Ut & 1.5 & $\begin{array}{l}\text { Slightly elevated } \\
\text { yellowish lesion }\end{array}$ & $\begin{array}{l}\text { Aggregation of minute } \\
\text { yellowish spots with tortu- } \\
\text { ous microvessels inside }\end{array}$ & $\begin{array}{l}\text { Foam cells in the } \\
\text { papillae }\end{array}$ & $\begin{array}{l}\text { Posi- } \\
\text { tive }\end{array}$ & Positive \\
\hline
\end{tabular}
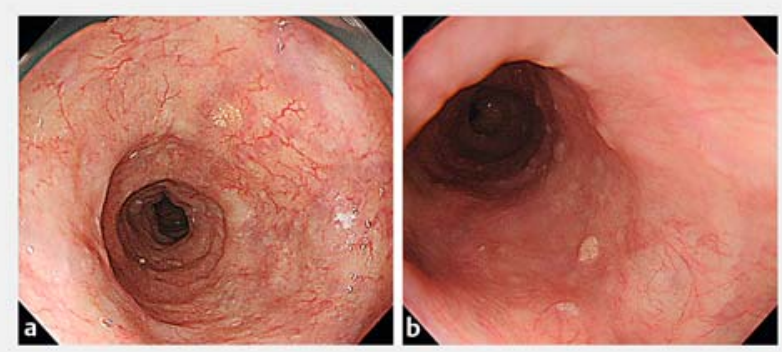

Fig. 1 Non-magnifying endoscopy showing esophageal xanthomas. a A flat area with yellowish granular spots in Patient 4. b A slightly elevated yellowish lesion in Patient 1.

in the upper ( $n=3)$ or cervical $(n=2)$ esophagus. Endoscopically, four lesions appeared as flat areas with yellowish granular spots ( $\triangleright$ Fig. 1a) and three as slightly elevated yellowish lesions ( $\triangleright$ Fig.1b). Magnifying white-light endoscopy revealed the lesions to be aggregates of minute yellowish spots with tortuous microvessels inside; this was the case in all six lesions apart from one where magnifying endoscopy was not performed ( $\vee$ Fig.2a,b). In all lesions, magnifying NBI contrasted the yellowish spots and microvessels inside more clearly than whitelight endoscopy ( $>$ Fig.3a,b). In all lesions, histological exami-

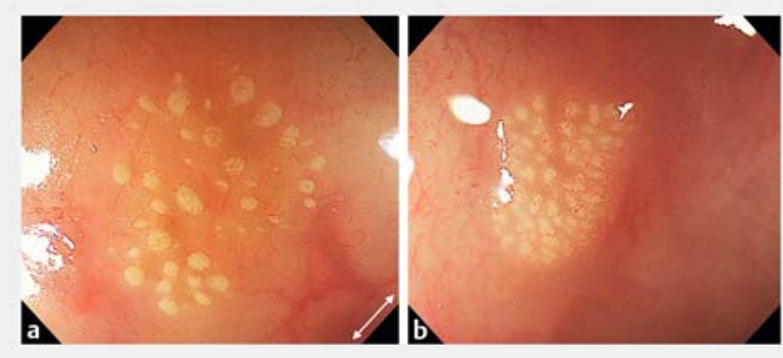

- Fig. 2 Magnifying white light images showing esophageal xanthomas. An aggregation of minute yellowish spots with tortuous microvessels on their surface is shown in (a) Patient 4 and (b) Patient 1 . The white arrow in (a) is $0.6 \mathrm{~mm}$ in length.

nations showed that the yellowish spots corresponded to papillae filled with foam cells. In two lesions, the foam cells were also seen in the lamina propria mucosae ( $\mathbf{F i g . 4 a , b ) . ~ F o a m ~ c e l l s ~}$ were strongly immunopositive for CD68 in all six lesions, apart from one in which the lesion could not be identified in the prepared slice used for immunohistochemical staining ( $\triangleright$ Fig. 4c,d). In all lesions, immunohistochemical staining for CD34 showed intrapapillary capillaries around the aggregated

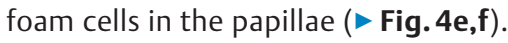




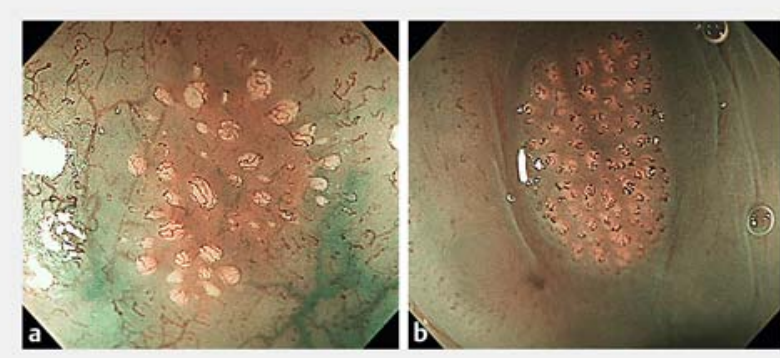

- Fig.3 Magnifying narrow-band images showing esophageal xanthomas. Minute yellowish spots with tortuous microvessels on the surface are clear in (a) Patient 4 and (b) Patient 1.

\section{Discussion}

In this retrospective observational study of esophageal xanthomas, magnifying endoscopy revealed an aggregation of minute yellowish spots with tortuous microvessels. These findings are unique and were similarly observed in all lesions regardless of their non-magnifying endoscopic appearance (flat or slightly elevated). Due to their rareness, the characteristic endoscopic appearance, etiology, and clinical significance of esophageal xanthomas are not well known. Previous reports have suggested the endoscopic findings of esophageal xanthomas to be yellowish granular spots, yellowish elevated lesions, yellow-white colored plaques, or yellow verruciform lesions, measuring from 2 to $20 \mathrm{~mm}$ (usually $\leq 5 \mathrm{~mm}$ ) [4-17]. However, no previous report has described the magnifying endoscopic appearance of esophageal xanthomas.

In the present study, using non-magnifying endoscopy, four lesions were present as flat areas with yellowish granular spots and three appeared as slightly elevated yellowish lesions; median size of the lesions was $2 \mathrm{~mm}$ (range, $1-5 \mathrm{~mm}$ ). These findings are consistent with those reported in previous articles [4-17]. Lesions presenting as flat areas with yellowish granular spots are unique, even in non-magnifying endoscopic appearance. Considering the results of the present study, for these flat lesions, a diagnosis of esophageal xanthomas can be made relatively easily and a biopsy may be unnecessary in these cases.

However, slightly elevated yellowish lesions may be difficult to identify from only non-magnifying images, making diagnosis of esophageal xanthoma more complicated. Under non-magnifying endoscopy, some esophageal xanthomas can be misdiagnosed as ectopic sebaceous glands, malignant lymphomas, or papillomas [5-7]. Therefore, biopsy is recommended for such slightly elevated yellowish lesions if magnifying endoscopy is unavailable. Use of magnifying endoscopy, however, may solve this problem. In magnifying endoscopic images, both flat lesions with yellowish granular spots and slightly elevated yellowish lesions have a similar appearance, with aggregates of minute yellowish spots with tortuous microvessels inside. With the maximum magnification, a short side of the octagonal endoscopic image frame measures $0.6 \mathrm{~mm}$ in length ( $\mathbf{F i g . 2 a}$, - Supplementary Fig. e1); therefore, the size of each yellowish nodule is estimated to be $0.1-0.3 \mathrm{~mm}$, which is the same size as the papillae filled with aggregated CD68-positive foam cells in histological images ( $\triangleright$ Fig. 4c,d).

Moreover, immunohistochemical staining for CD34 showed that intrapapillary capillaries surrounded the foam cells in the papillae, which is suggestive of the tortuous microvessels on the surface of the yellowish spots. Accordingly, the magnifying endoscopic images correspond well with the histological findings of esophageal xanthoma; this unique endoscopic appearance may make the diagnosis of esophageal xanthomas easier. A difference in non-magnifying endoscopic appearance between flat areas with yellowish granular spots and slightly elevated yellowish lesions is considered to represent a difference in density of the minute yellowish spots, that is, papillae filled by foam cells. To the best of our knowledge, the reason why foam cells aggregate mainly in the papillae, not homogeneously in the lamina propria mucosae, is as yet unknown. However, many cases of esophageal xanthomas have shown this particular histological finding $[6,7,9,11-13,16,17]$. Moreover, xanthomas in other organs covered with squamous epithelium, such as the pharynx or oral cavity, also show the same finding [19-21]. Therefore, this finding would be characteristic of xanthomas in the squamous epithelium.

The etiology and clinical significance of esophageal xanthomas remain largely unknown. In the present study, all patients had a history of both drinking and smoking, and the majority of patients had a history of either esophageal or head and neck cancers; drinking and smoking are well known risk factors for esophageal or head and neck cancers [18]. On the other hand, mucosal damage caused by several inciting agents has been presumed to play a major role in the pathogenesis of gastrointestinal xanthomas [6,7]. Mucosal damage caused by alcohol consumption and tobacco smoking over a long period of time may contribute to the development of esophageal xanthoma, sharing a similar pathogenesis to esophageal or head and neck cancers. In this regard, esophageal xanthoma is speculated to be a high risk marker for the development of esophageal or head and neck cancers, in the same way that gastric xanthoma is suggested to be a high risk marker for gastric cancers [2]. According to previous case reports of esophageal xanthoma, 10 of 15 patients were men [4-7,9-17]. Similarly, in the present study, the lesions were detected mainly in men. Usual habits of alcohol consumption and tobacco smoking in elderly men may contribute to the male predominance of esophageal xanthomas. Four of the seven patients in the present study had a history of radiation therapy in the area with esophageal xanthoma. There have been two previously reported cases of esophageal xanthoma that developed in patients with a history of radiotherapy, suggesting a possible pathogenesis of the disease [7, 12]. However, as all four patients also had a history of drinking, smoking, and esophageal or head and neck cancers, the role of radiation therapy remains unknown. To date, no apparent relationship between esophageal xanthoma and hyperlipidemia has been indicated [15].

The present study has some limitations. First, the sample size was very small. However, esophageal xanthomas are considered to be rare and only 17 cases have been described in the English literature before the cases described here. The pres- 

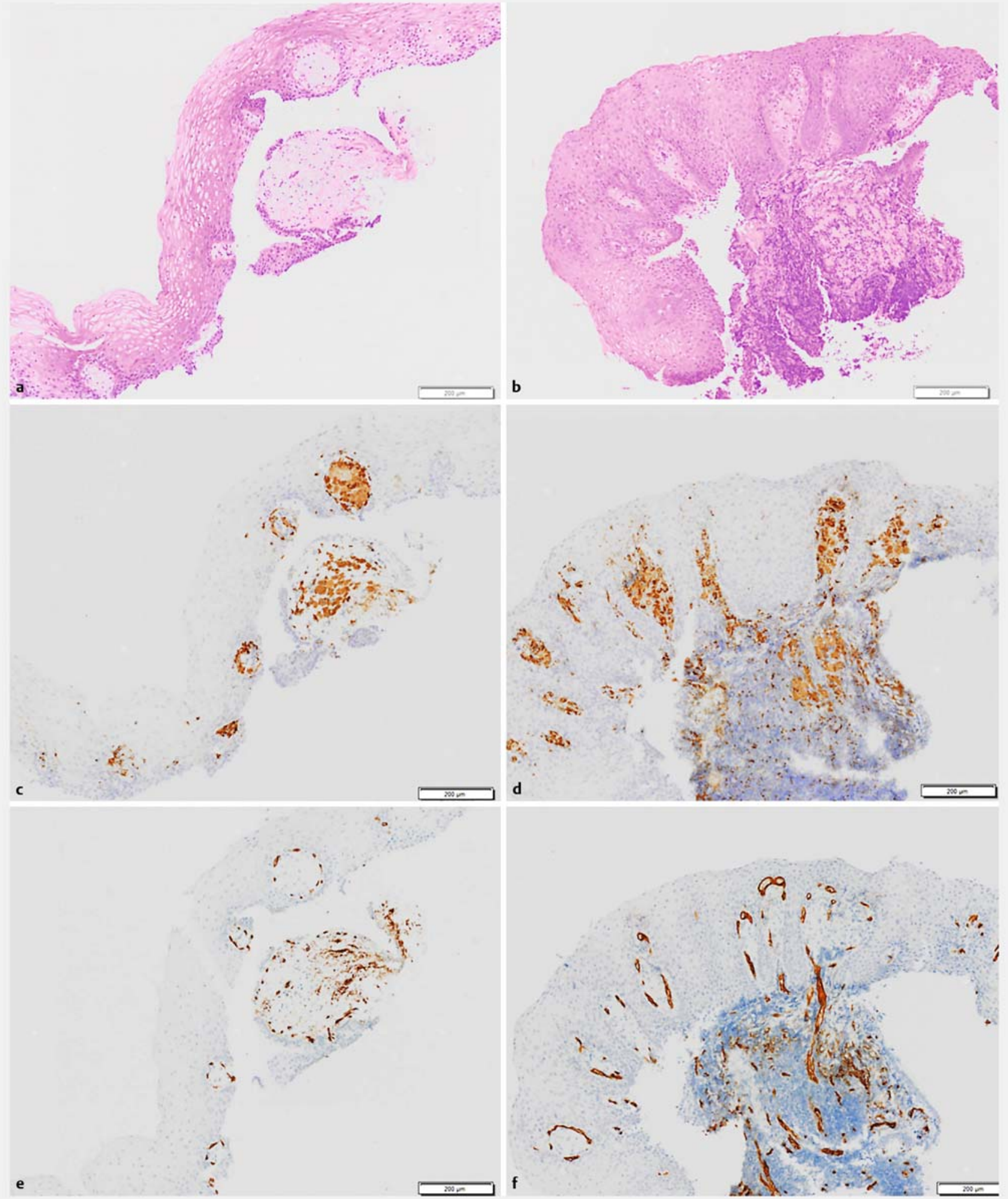

- Fig. 4 Histological examination and immunohistochemical staining with antibodies to CD68 and CD34. Foam cells filling the papillae and lamina propria mucosae in (a) Patient 4 and (b) Patient 1; foam cells strongly immunopositive for CD68 in (c) Patient 4 and (d) Patient 1; immunohistochemical staining for CD34 showing intrapapillary capillaries around the foam cells in (e) Patient 4 and (f) Patient 1 . The white bars in images are $0.2 \mathrm{~mm}$ in length. 
ent study included no less than seven consecutive cases, and despite these originating from a single center, their contribution is still valuable. In the present study, after the first detection of an esophageal xanthoma, the others were detected over a short period, indicating that esophageal xanthomas were probably often missed during routine endoscopy; this is likely because most endoscopists are unfamiliar with the endoscopic characteristics of the lesions. Therefore, esophageal xanthomas may be more common than previously thought. If endoscopists recognized the characteristics indicated in this study, the lesions would be detected more frequently; thus, the etiology, clinical significance, and natural history of esophageal xanthomas could be fully elucidated. Second, because the cases were enrolled in a tertiary cancer center, there may be a selection bias for patients at high risk for cancers, such as those with a habit of drinking and smoking. Therefore, the data with regard to the prevalence and risk factors of the disease should be validated in the general population.

In conclusion, the yellowish spots with tortuous microvessels inside, as identified by magnifying endoscopic images, represent unique and characteristic findings of esophageal xanthoma. These findings correspond well with histological findings and as such, they may assist in the endoscopic diagnosis of the lesion.

\section{Competing interests}

\section{None}

\section{References}

[1] Stiff KM, Cohen PR. Vegas (verruciform genital-associated) xanthoma: a comprehensive literature review. Dermatol Ther (Heidelb) 2017; 7 : $65-79$

[2] Sekikawa A, Fukui H, Sada R et al. Gastric atrophy and xanthelasma are markers for predicting the development of early gastric cancer. J Gastroenterol 2016; 51: 35-42

[3] Kimura K, Hiramoto T, Buncher CR. Gastric xanthelasma. Arch Pathol 1969; 87: $110-117$

[4] Remmele W, Engelsing B. Lipid island of the esophagus. Case report. Endoscopy 1984; 16: $240-241$
[5] Vimala R, Ananthalakshmi V, Murthy M et al. Xanthelasma of esophagus and stomach. Indian J Gastroenterol 2000; 19: 135

[6] Hirokawa M, Takenaka R, Takahashi A et al. Esophageal xanthoma: report of two cases and a review of the literature. J Gastroenterol Hepatol 2003; 18: 1105-1108

[7] Herrera-Goepfert R, Lizano-Soberón M, García-Perales M. Verruciform xanthoma of the esophagus. Hum Pathol 2003; 34: 814-815

[8] Gencosmanoglu R, Sen-Oran E, Kurtkaya-Yapicier O et al. Xanthelasmas of the upper gastrointestinal tract. J Gastroenterol 2004; 39: $215-219$

[9] Licci S, Campo SM, Ventura P. Verruciform xanthoma of the esophagus: an uncommon entity in an unusual site. Endoscopy 2010; 42: (Suppl. 02): E330

[10] Becheanu G, Dumbrava M, Arbanas T et al. Esophageal xanthoma report of two new cases and review of the literature. J Gastrointest Liver Dis 2011; 20: 431 -433

[11] Min KW, Koh JS, Lee KG et al. Verruciform xanthoma arising in the mid esophagus. Dig Endosc 2012; 24: 387

[12] Salamanca J, Alemany I, Sosa G et al. Esophageal verruciform xanthoma following radiotherapy. Gastroenterol Hepatol 2012; 35: 317 320

[13] Park HS, Jang KY, Moon WS. Incidental esophageal xanthoma in a patient with ileocecal lymphoma. Dig Endosc 2013; 25: 92 - 93

[14] Bang CS, Kim YS, Baik GH et al. Xanthoma of the esophagus. Clin Endosc 2014; 47: 358 - 361

[15] Díaz Del Arco C, Álvarez Sánchez Á, Fernández Aceñero MJ. Non-gastric gastrointestinal xanthomas: case series and literature review. J Gastrointest Liver Dis 2016; 25: 389-394

[16] Uehara K, Iwashita H, Tanabe Y et al. Esophageal xanthoma: presence of M2 macrophages suggests association with late inflammatory and reparative processes. Open Med (Wars) 2017; 12: 335 - 339

[17] Hamada K, Yamasaki Y, Kubota Jl et al. Yellowish lesions in the oesophagus. Gut 2019; 68: 39-158

[18] Secretan B, Straif K, Baan R et al. A review of human carcinogens Part E: tobacco, areca nut, alcohol, coal smoke, and salted fish. Lancet Oncol 2009; 10: $1033-1034$

[19] Hamada K, Takeuchi Y, Kubo C et al. Sporadic minute pharyngeal xanthomas detected incidentally during esophagogastroduodenoscopy: a case series. Head Neck Pathol 2019; 13: 277-280

[20] Hamada K, Tanaka T, Kawahara Y et al. A pharyngeal xanthoma detected during esophagogastroduodenoscopy screening. Gastrointest Endosc 2019: doi:10.1016/j.gie.2019.04.221 [Epub ahead of print]

[21] Harris L, Staines K, Pring M. Oral verruciform xanthoma. BM] Case Rep 2015; 2015: bcr2014209216 


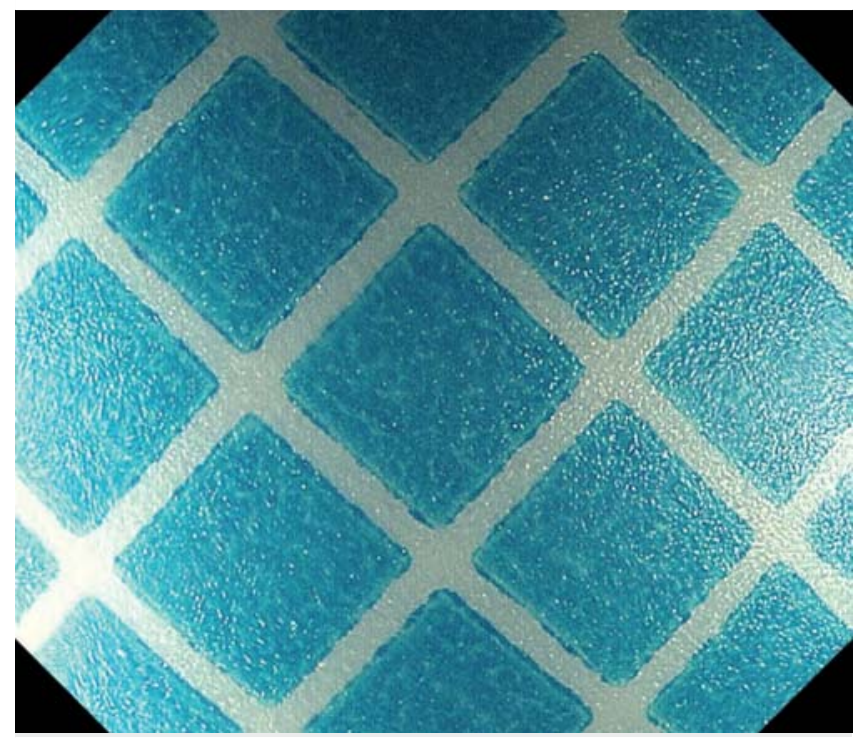

- Fig.e1 Supplementary Graph paper observed using endoscope GIF-H260Z with maximum magnification. Lines are drawn at 1-mm intervals. 